\title{
Analisis Implementasi Kebijakan Program Penanggulangan Stunting Terintegrasi Di Kabupaten Lombok Utara
}

\author{
Hermawati ${ }^{1}$, Sastrawan ${ }^{2}$ \\ e-mail :hermawatiskm7@gmail.com \\ ${ }^{1}$ Dinas Kesehatan Kabupaten Lombok Utara \\ ${ }^{2}$ Universitas Qamarul Huda Badaruddin
}

\begin{abstract}
ABSTRAK
Intervensi penurunan stunting dengan berbagai program di tingkat administrasi sangat lemah sehingga perlu dideskriptifkan analisis implementasi kebijakan program penanggulangan stunting terintegrasi di Kabupaten Lombok Utara tahun 2020. Metode yang digunakan dalam penelitian ini adalah penelitian kualitatif deskriptif, sedangkan yang menjadi sumber data dalam penelitian ini yaitu Dinas Kesehatan, Sekertariat Daerah, Badan Perencanaan Pembangunan Daerah, Dinas Pengendalian Penduduk, Keluarga Berencana, Pemberdayaan Masyarakat dan Desa (DP2KBPMD) Kabupaten Lombok Utara. Selanjutnya, tujuan dalam penelitian ini adalah bagaimana implementasi kebijakan program penanggulangan stunting terintegrasi di Kabupaten Lombok Utara. Berdasarkan hasil analisis dan pembahasan diatas dapat disimpulkan bahwa program penanggulangan stunting terintegrasi belum sepenuhnya bisa berjalan dengan maksimal karena bayaknya kendala tehnis yang terjadi pada saat pelaksanaan program kegiatan dimasing-masing OPD di lapangan.
\end{abstract}

Kata Kunci: Implementasi, kebijakan, program, stunting

\begin{abstract}
Interventions for reducing stunting with various programs at the administrative level are very weak, so it is necessary to describe an analysis of the implementation of policies for the integrated stunting reduction program in Kabupaten Lombok Utara in 2020. The method used in this research is descriptive qualitative research, while the data sources in this study are the Health Office, Regional Secretariat, Regional Development Planning Agency, Population Control Office, Family Planning, Community and Village Empowerment (DP2KBPMD) North Lombok Regency. Furthermore, the purpose of this research is how to implement an integrated stunting prevention program policy in North Lombok Regency. Based on the results of the analysis and discussion above, it can be concluded that the integrated stunting management program has not been fully implemented due to the many technical problems that occurred during the implementation of program activities in each OPD in the field.
\end{abstract}

Keywords: Implementation, Policy, Program, Stunting

\section{A. PEndahuluan}

Penyelenggaraan intervensi penurunan stunting terintegrasi merupakan tanggung jawab bersama lintas sektor dan bukan tanggung jawab salah satu institusi saja. Untuk itu, diperlukan sebuah tim lintas sektor sebagai pelaksana Aksi Integrasi.
Keanggotaan tim lintas sektor tersebut sekurang-kurangnya mencakup instansi yang menangani: kesehatan, pertanian, ketahanan pangan, kelautan dan perikanan, pendidikan, perindustrian, sosial, agama, komunikasi dan informasi, pekerjaan umum/cipta karya/perumahan dan pemukiman, 
pemberdayaan masyarakat desa, pemberdayaan perempuan dan perlindungan anak, kependudukan catatatan sipil dan keluarga berencana, dan pengawasan obat dan makanan.

Secara umum koordinasi program di berbagai tingkat admnistrasi sangat lemah, hal itu bisa dilihat di lapangan (kabupaten, kecamatan maupun desa) berbagai kegiatan yang terkait dengan penyelenggaraan intervensi gizi spesifik dan sensitif masih belum terpadu, baik dari proses perencanaan dan penganggaran, pelaksanaan, pemantauan, maupun evaluasi. Akibatnya cakupan dan kualitas berbagai pelayanan kurang optimal. untuk itu penyelenggaraan intervensi Gizi sensitif dan intervensi Gizi spesifik perlu dilakukan dengan pendekatan konvergensi multi sektor dimana semua pemangku kebijakan dari tingkat pusat hingga desa paham peran dan tanggung jawabnya dalam penanggulangan stunting.

Hasil wawancara awal dengan Kepala seksi gizi dari Dinas Kesehatan juga menyatakan bahwa sudah banyak upaya yang dilakukan dalam menekan angka stunting di Kabupaten Lombok Utara bahkan inovasi juga ada salah satunya seperti Saber Gebuk (Sapu Bersih Entaskan Gizi Buruk dan Kurang) yaitu gerakan para pemangku kepentingan di kabupaten Lombok Utara untuk mengurangi angka gizi buruk dan gizi kurang serta stunting. Lalu dicanangkannya Desa bersih dan sehat (Debest) pada tahun 2018 karena untuk menurunkan angka gizi buruk dan gizi kurang tentu tidak bisa terlepas dari pola hidup bersih masyarakat. namun masih juga belum bisa menurunkan prevalensi stunting secara signifikan. Sehingga kita berharap peran OPD dan lembaga lain dalam membantu memaksimalkan program pemerintah baik di kabupaten, kecamatan dan desa dalam menaggulangi stunting di lombok utara.

Dengan demikian Pemerintah Kabupaten Lombok Utara mengeluarkan kebijakan melalui Peraturan Bupati Nomor 16 tahun 2019 tentang Upaya Penanggulangan Stunting Terintegrasi. Dimana melalui regulasi tersebut dilakukan intervensi gizi spesifik yang ditujukan pada anak 1000 HPK (Hari Pertama Kehidupan) yang dilakukan oleh sektor kesehatan dan intervensi gizi sensitif yang akan dilakukan oleh lintas sektor dengan sasaran semua masyarakat. Peraturan ini dibuat dengan tujuan meningkatkan status gizi masyarakat dan kualitas sumber daya manusia dengan strategi yang akan dilakukan adalah edukasi, pelatihan dan penyuluhan kesehatan dan gizi melalui kemandirian keluarga, gerakan masyarakat hidup sehat, dan memperkuat gerakan seribu hari pertama kehidupan. Berdasarkan penjelasan diatas peneliti tertarik untuk meneliti bagaimana peran dinas kesehatan dan OPD/Lembaga terkait dalam mengimplementasikan kebijakan pemerintah tentang upaya penanggulangan stunting terintegrasi dengan mengangkat judul "Analisis Implementasi Kebijakan Program Penanggulangan Stunting Terintegrasi di kabupaten Lombok Utara"

\section{B. METODE PENELITIAN}

Penelitian ini adalah jenis penelitian yang menggunakan penelitian kualitatif deskriptif, yang pada akhirnya diselesaikan dengan data dalam bentuk kata-kata, gambar, bukanlah angka-angka. Penelitian kualitatif adalah prosedur penelitian yang menghasilkan data deskriptif berupa kata-kata tertulis atau lisan dari orang-orang dan perilaku yang diamati.

Sehingga dalam penelitian ini tentunya dilakukan untuk menggambarkan atau mendeskriptifkan analisis implementasi kebijakan program penanggulangan stunting terintegrasi di Kabupaten Lombok Utara tahun 2020. Dalam penelitian ini menggunakan pendekatan penelitian kualitatif dengan menggunakan metode fenomenologi.

Adapun yang menjadi sumber data dalam penelitian ini adalah : 
a. Penanggung jawab program gizi pada Dinas Kesehatan Kabupaten lombok Utara yaitu Kepala seksi gizi

b. Kepala Bidang Sosial Budaya pada Badan Perencanaan Pembangunan Daerah (BAPPEDA) Kabupaten Lombok Utara

c. Kepala Sub Bagian Kesejahteraan dan Fasilitasi Layanan Dasar pada Sekertariat Daerah Kabupaten Lombok Utara sebagai pemantau dalam pelaksanaan implementasi kebijakan program penanggulangan stunting di kabupaten

d. Kepala Bidang Advokasi Penggerakan dan informasi, Kesejahteraan Keluarga (ADVIN,KS) pada Dinas Pengendalian Penduduk, Keluarga Berencana, Pemberdayaan Masyarakat dan desa (DP2KBPMD)

e. Kepala Bidang Rehabilitasi Sosial pada Dinas Sosial Perlindungan Perempuan dan Anak (DINSOS PPPA) Kabupaten Lombok Utara

Dalam pengambilan data dilapangan, peneliti dibantu oleh pedoman wawancara, alat rekam dan alat dokumentasi. Hal ini dilakukan untuk memudahkan peneliti dalam pengambilan dan pengumpulan data.

Sebagaimana yang telah diketahui bahwa, analisis kualitatif berangkat dari metode fenomenologi yang digunakan untuk menganalisis makna dari data yang tampak dipermukaan. Analisis data dalam penelitian kualitatif adalah proses sistematis untuk mencari dan mengatur transkrip wawancara, catatan lapangan, dan materi-materi lain untuk menemukan apa yang penting dilaporkan kepada orang lain sebagai temuan penelitian.

Dalam penelitian kualitatif proses sintematis untuk mengatur transkrip wawasan, materi yang ada dan catatancatatan untuk menemukan temuan penting yang akan dilaporkan sebagai hasil yang akan dilaporkan kepada orang lain.

Analisis data dilakukan bertujuan untuk mengetahui hasil dari data yang dikumpulkan dari beberapa metode yang ada, hingga dapat diketahui keakuratan dan validnya data yang ada. Kemudian dalam penelitian ini peneliti menggunakan teknik analisis deskriptif yang penelitiannya dilakukan dengan cara observasi, wawancara dan dokumentasi. Setelah seluruh data yang dibutuhkan dan terkumpul yang sudah diperoleh dari beberapa sumber atau informan di Dinas Kesehatan, Sekertariat Daerah, Badan Perencanaan Pembangunan Daerah, Dinas Pengendalian Penduduk, Keluarga Berencana, Pemberdayaan Masyarakat dan Desa (DP2KBPMD) Kabupaten Lombok Utara dengan menggunakan beberapa teknik yang ada kemudian diolah dengan metode dan mengalir (flow model) seperti pendapat Miles dan Huberman yang dikutip dalam buku karangan Sugiyono (2013), setelah data terkumpul kemudian data yang diperoleh disajikan (display data), dan kemudian diakhiri dengan sebuah kesimpulan (verivication). Yang tahap ini dilakukan secara terus menerus setelah selesai mengumpulkan data sampai data itu selesai diolah.

\section{HASIL DAN PEMBAHASAN \\ 1. Gambaran Umum Lokasi Penelitian}

Kabupaten lombok utara merupakan kabupaten termuda di Provinsi Nusa Tenggara Barat. Batas wilayah kabupaten lombok utara adalah sebagai berikut :

1. Sebelah utara berbatasan langsung dengan laut jawa

2. Sebelah selatan berbatasan dengan lombok barat

3. Sebelah timur berbatasan dengan lombok tengan dan lombok timur

4. Sebelah barat berbatasan dengan selat lombok

Luas kabupaten lombok utara adalah 80,953 hektar. Sebagian besar lahan yang ada di kabupaten lombok utara merupakan lahan bukan sawah terutama untuk lahan kebun dan 
hutan.lahan yang digunakan sebagai lahan sawah berkisar 9.331 hektar. Secara admnistratif terbagi menjadi 5 kecamatan yaitu kecamatan Bayan, Kayangan, Gangga, Tanjung dan Pemenang dan terdiri dari 33 desa dan 371 dusun, yang mana kecamatan Bayan memiliki luas wilayah terbesar dengan luas wilayah $329,10 \mathrm{~km}^{2}$ dan terkecil adalah kecamatan Pemenang dengan luas wilayah $81,09 \mathrm{~km}^{2}$

\section{Karaktristik Informan Penelitian}

Pengumpulan data dilakukan dengan menggunakan pedoman wawancara terhadap informan yang dijadikan narasumber penelitian. Jumlah informan dalam penelitian ini sebanyak 5 orang. Adapun informan tersebut terdiri dari 1 orang kepala seksi gizi pemegang program penanggulangan stunting pada Dinas Kesehatan Kabupaten Lombok Utara, 1 orang kepala sub bagian kesejahteraan dan fasilitasi layanan dasar pada Sekertariat Daerah, 1 orang kepala bidang sosial budaya pada badan perencanaan pembangunan daerah, 1 orang kepala bidang advokasi penggerakan dan informasi, kesejahteraan keluarga pada Dinas Pengendalian Penduduk, keluarga Berencana, Pemberdayaan Masyarakat dan Desa (DP2KBPMD), dan 1 orang kepala bidang penataan dan admnistrasi desa pada Dinas Pengendalian Penduduk, keluarga Berencana, Pemberdayaan Masyarakat dan Desa (DP2KBPMD) Kabupaten Lombok Utara. Adapun karaktristik informan berdasarkan hasil penelitian dapat terlihat pada tabel berikut.

\section{Implementasi Program Penanggulangan Stunting Terintegrasi \\ 3.1 Pelaksanaan Program}

Berdasarkan Surat Keputusan Bupati Lombok Utara Nomor 22.A/2.43 tahun 2019 tentang pembentukan tim koordinasi penanggulangan stunting kabupaten lombok utara bahwa dalam rangka penanggulangan stunting di kabuapaten lombok utara melalui penanganan secara meyeluruh maka, perlu membentuk tim koordinasi penanggulangan stunting dengan melibatkan seluruh OPD terkait yang bisa mendukung pelaksanaan program secara terpadu dan terintegrasi tentunya hal ini dilakukan secara berjenjang dan membutuhkan kerjasama yang intens dalam pelaksanaan program.

Berdasarkan hasil penelitian yang didapatkan, implementasi kebijakan penanggulangan stunting yang sudah dilakukan oleh Dinas Kesehatan menurut hasil wawancara dengan pengelola program gizi di Dinas Kesehatan Kabupaten Lombok Utara yaitu pemberian tablet tambah darah pada ibu hamil, pemberian PMT pemulihan Bumil KEK, pemberian PMT bagi Balita kurus, pemberian ASI hingga 24 bulan, pemberian makanan pendamping asi (MP-ASI) untuk anak, memberikan obat cacing, memberikan imunisasi dasar lengkap kepada anak, pemberian vitamin $\mathrm{A}$, memberikan pelayanan pencegahan dan pengobatan diare serta memberikan suplemen zink dan memberikan edukasi dan informasi seputar stunting dan gizi kepada masyarakat melalui kelas balita dan kelas ibu hamil. Itu semua kami sudah lakukan dalam mengintervensi gizi spesifik dalam upaya penurunan stunting di Kabupaten Lombok Utara namun upaya ini tentunya tidak akan berhasil jika OPD lain tidak ikut berperan aktif dalam membantu kami menurunkan prevalensi stunting sebab upaya yang kami lakukan hanya berkontribusi sebesar $30 \%$ dalam intervensi 1000 HPK.

Penurunan stunting melalui intervensi gizi sensitif yang berkontribusi sebesar $70 \%$ ditujukan melalui berbagai kegiatan di sektor lain seperti Dinas Pengendalian Penduduk, Keluarga Berencana, Pemberdayaan Masyarakat dan Desa dalam program ini dilakukan kerjasama dalam melakukan penyuluhan ke desa-desa lokasi intervensi stunting. Kegiatan yanng dilakukan seperti penyuluhan tentang pola asuh atau parenting melalui pendekatan 8 fungsi keluarga. DP2KBPMD juga memiliki program dalam penanggulangan stunting seperti pembentukan kelompok Bina Keluarga Balita (BKB) yang terintegraasi dengan PAUD dan Posyandu, 
penyuluhan tentang 1000 HPK ke masyarakat yang memiliki bayi berusia dua tahun (BADUTA) melalui media KIE, pembinaan kepada Kader Pembangunan Manusia (KPM) dan pendamping-pendamping desa seperti PLKB dan SPMD tentang 1000 HPK, Pusat Informasi Konseling Remaja (PIK-R) sebagai wadah untuk remaja dalam memberikan informasi dan konseling tentang perencanaan kehidupan berkeluarga yang berkualitas melalui Generasi Berencana (GENRE) sehingga dalam merencanakan suatu pernikahan sudah siap secara mental dan materia sehingga tidak terjadi pernikahan di usia anak yang bisa berdampak pada generasi penerusnya seperti salah satu dampaknya yaitu stunting semua itu dilakukan oleh bidang Advokasi Penggerakan dan Informasi, Kesejahteraan Keluarga (ADVIN,KS). penyusunan regulasi kewenangan desa dalam penggunaan dana desa serta advokasi kepala desa dalam penggunaan dana desa untuk program stunting oleh bidang Penataan dan Admnistrasi Desa.

Upaya penurunan stunting melalui intervensi gizi sentisif juga dilakukan oleh beberapa dinas terkait seperti Dinas Sosial yang memberikan program keluarga harapan, bantuan non tunai dan jaminan kesehatan masyarakat.

Hasil wawancara dengan Kepala Bidang Sosial Budaya (SOSBUD) pada Badan Perencanaan Pembangunan Daerah (BAPPEDA) juga menyatakan bahwa dinas lain yang harus ikut bergerak dalam menuntaskan masalah stunting ini adalah Dinas Pembangunan Umum (PU) dan Dinas Lingkungan Hidup (LH) dimana mereka harus melakukan penyediaan sarana dan akses air minum yang bersih dan aman, serta sarana sanitasi yang layak, penyedaan sanitasi yang layak untuk rumah tangga, kemudia rumah sehat dan layak huni. Selanjutnya Dispora yang menyiapkan ketersediaan data cakupan anak usia 2-6 tahun yang terdaftar sebagai peserta didik, peningkatan kompetensi pendidik dan pengembangan PAUD. Selanjutnya Dinas Ketahanan Pangan dan Pertanian kita gencarkan untuk Kawasan Rumah Pangan Lestari (KRPL), peningkatan mutu dan keamanan pangan dan lumbung pangan.

Dari sekian banyaknya program yang harus dipadukan dalam penanggulangan stunting di kabupaten kami berupaya melakukan bimbingan dengan mengajak berdiskusi dengan OPD tehnis untuk memberikan edukasi dan dorongan serta mempropokasi pelaksana kegiatan supaya lebih intes berkoordinasi dan mengintegrasikan kegiatan sehingga menghasilkan outcam yang tidak hanya sekedar penyelesaian admnistrasi program semata seperti yang biasa dilakukan di seluruh OPD yang bersangkutan, dimana suatu program kegiatan hanya menghasilkan angka bukan rasa sehingga semua program yang dilakukan tidak dirasakan manfaatnya oleh masyarakat. Sehingga dampaknyapun tidak begitu signifikan dalam menurunkan prevalensi stunting yang semakin meluas di Kabupaten Lombok Utara dengan bertambahnya desa lokus stunting di desa.

\subsection{Pelaksanaan Koordinasi program}

Berdasarkan hasil penelitian yang didapatkan melalui wawancara dengan informan yang sudah dipilih oleh peneliti menyatakan bahwa implementasi kebijakan program penanggulangan stunting di Kabupaten Lombok Utara sudah dilakukan oleh semua OPD terkait bahkan pelaksanaan dari rencana kegiatan stunting sudah berdasarkan rancangan yang telah disepakati oleh masingmasing OPD pelaksana. Namun dalam proses pelaksanaan program ada beberapa kegiatan yang belum maksimal dilakukan diantaranya yaitu pemerataan distribusi Tablet Tambah Darah (TTD) remaja putri melalui sekolah, cakupan orang tua yang mengikuti kelas parenting, ketersediaan data cakupan anak usia 2-6 tahun yang terdaftar sebagai peserta didik serta cakupan rumah tangga yang mendapatkan Jaminan Kesehatan Nasional (JKN)/Jamkesda. Hal ini merupakan sebagian dari beberapa 
program kegiatan yang belum dikoordinasikan dengan baik dengan OPD pelaksana masingmasing kegiatan seperti DISPORA, DP2KBPMD, DINSOS PPPA dan masih banyak lagi pelaksanaan program kegiatan lainnya yang tidak bisa di lakukan secara terpadu karena jadwal pelaksanaan kegiatan yang belum diintegrasikan dan dikoordinasikan secara bersama-sama oleh pelaksana kegiatan. Sehingga banyak program terpadu dalam upaya penanggulangan stunting terintegrasi tidak bisa dipadukan.

Pelaksanaan penanggulangan stunting terintegrasi sudah dilakukan secara berjenjang tetapi masih banyak menemukan hambatanhambatan dalam pelaksanaanya hal itu bisa dilihat juga dari metode pendekatan perubahan prilaku masyarakat untuk kesadaran bergizi yang kurang efektif, koordinasi antara pelaksana program penanggulangan stunting terintegrasi masih kurang, serta keterlibatan pemangku kebijakan di desa dan pendampingpendamping desa masih sangat lemah.

Penguatan kapasitas pencapaian outcome program melalui penguatan peran pemantauan unit kerja kesejahteraan masyarakat bagian kesra, kecamatan dan desa, penajaman program melalui penyesuaian jumlah program dengan ketersediaan sumber daya manusia dan waktu kerja guna memastikan bahwa perencanaan, pelaksanaan, pemantauan dan evaluasi berjalan secara efektif sehingga tercapainya outcome program yang berkualitas, serta kepastian pemantauan dilakukan pada tahun berjalan, 1 tahun dan 2 tahun pasca program dan evaluasi paruh waktu masa jabatan kepala daerah guna memastikan ketercapaian program.

\section{KESIMPULAN DAN SARAN}

Berdasarkan hasil analisis dan pembahasan diatas dapat disimpulkan bahwa program penanggulangan stunting terintegrasi belum sepenuhnya bisa berjalan dengan maksimal karena bayaknya kendala tehnis yang terjadi pada saat pelaksanaan program kegiatan dimasing-masing OPD di lapangan. Lemahnya koordinasi dari masing-masing OPD merupakan hal yang paling sering terjadi karena lemahnya sumber daya manusia dimana di setiap OPD kekurangan tenaga pelaksana program, penempatan yang tidak sesuai dengan besik keilmuannya, kemudian tingginya rutinitas program prioritas lainnya yang harus dilaksanakan sehingga berdampak pada tidak maksimalnya tenaga yang ada dalam mengemban tugas fungsinya dalam melaksanakan rutinitas program yang sangat padat, tidak adanya tenaga ahli dalam membantu mengkaper program yang ada.

Anggaran yang belum bisa dimobilisasi secara efektif dan efisien sehingga perencanaan program kegiatan penanggulangan stunting terintegrasi perlu perbaikan manajemen layanan untuk memastikan layanan menjangkau rumah tangga 1000 HPK bisa terlaksana. Peningkatan kapasitas guru PAUD, kader kesehatan, kader Bina Keluarga Balita (BKB) dan Kader Pembangunan Manusia (KPM), perkuat peran tim OPD dan desa dalam pelaksanaan evaluasi progran dan melakukan monev secara berjenjang sehingga hambatan dan keterbatasan-keterbatasan yang sudah diungkapkan oleh informan tersebut bisa diminimalisir.

Dalam penelitian ini ada beberapa saran kepada masyarakat dan pemerintah daerah yaitu:

1. Pentingnya peran aktif pemerintah daerah dalam penurunan stunting di kabupaten lombok utara

2. Program yang dilakukan terkait dengan stunting harus diperbaiki agar semua kalangan masyarakat merasakan dampak dan manfaatnya

3. Kerjasama antar OPD tehnis dan OPD terkait lainnya perlu ditingkatkan agar program penurunan stunting dapat berjalan dengan baik, terpadu dan terintegrasi.

\section{DAFTAR PUSTAKA}


[1] Ayuningtyas, D. (2014). Kebijakan Kesehatan: Prinsip dan Praktik (1st ed.). Jakarta: Rajawali Pers.

[2] Ayuningtyas, D. (2018). Analisis Kebijakan Kesehatan: Prinsip dan Aplikasi (1st ed.). Depok: Rajawali Pers.

[3] Buku saku desa dalam penanganan stunting. Buku Saku Desa Dalam Penanganan Stunting, 2-13.

[4] Dumilah Ayuningtyas. 2018. Analisis Kebijakan Kesehatan, Prinsip dan Aplikasi. Raja Grafindo Persada: 2018.

[5] Dun WN. 1998. Analisis kebijakan publik.

[6] Fikawati, S. (2017). Gizi Anak dan Remaja (1st ed.). Depok: Rajawali Pers. Gurning, F. P. (2018).

[7] Kemenkes RI. (2018a). Buletin Stunting. Kementerian Kesehatan RI, 1, 2. Kemenkes RI. (2018b). Kementerian Kesehatan Republik Indonesia.

[8] Kementerian Desa Pembangunan Daerah Tertinggal dan Transmigrasi. (2017).

[9] Kementerian Kesehatan RI. Sekretariat $r$ Jenderal. Rencana Strategis Kementerian Kesehatan Tahun Rencana Strategis Kementerian Kesehatan Tahun, p. 248. https://doi.org/351.077 Ind r

[10] Lexy J. Moleong, Metode Penelitian Kualitatif edisi revisi (Bandung: PT. Remaja Rosdakarya, 2013).

[11] Pius A purtanto \& M. Dahlan Al Barry, Kamus Ilmiah Populer (Surabaya: Arkola, 2001).

[12] Riskesdas. (2018). HASIL UTAMA RISKESDAS 2018 Kesehatan, Kementerian.

[13] Satrianegara, M. F. (2014). Organisasi dan Manajemen Pelayanan Kesehatan. Jakarta: Salemba Medika.
[14] Sugiyono, Metode Penelitian Kuantitatif Kualitatif dan R\&D (Bandung: Penerbit Alfabeta, 2013).

[15] Tohirin, Metodologi Penelitian Kuantitatif Dalam Pendidikan Dan Bimbingan Konseling,cet. Ke dua(Jakarta: Raja Grafindo Persada, 2012).

[16] Wahab SA, 1991, Analisis Kebijakan dari Formulasi ke Implementasi Kebijakan Negara, Bumi Aksara, Jakarta. 